\title{
Sztancs Edit': Az Európai Unió környezetvédelmi jogának alapelemei, különös tekintettel az uniós zajvédelmi szabályozásra
}

Debreceni Jogi Mühely, 2013. évi (X. évfolyam) 2. szám (2013. április) 52-60.

\section{A környezetvédelmi jog az alapszerződésekben}

Az Európai Közösségeket létrehozó szerződések eredetileg nem tartalmaztak a környezetvédelemre, környezetvédelmi jogra vonatkozó célkitüzéseket vagy rendelkezéseket, és ekként az Európai Közösségek környezeti politikával sem rendelkeztek, az teljes egészében a tagállamok hatáskörében volt. Ennek az indoka nem kizárólag a tagállamok integrációs célkitüzéseiben keresendő: az 1950-es években a nemzetközi környezetvédelmi jog is meglehetösen fejletlen volt - az első, nemzetközi színtéren igazán komoly áttörést csak az ENSZ 1972-ben Stockholmban megtartott nemzetközi környezetvédelmi konferenciája jelentette.

A környezetvédelmi jog nemzetközi jogi jelentőségének növekedésével párhuzamosan az Európai Közösségek is nyitott a környezetvédelmi kérdések közösségi szinten történő kezelése irányába: az 1972. októberi párizsi Európai Csúcsértekezleten környezetvédelmi akcióprogram kidolgozását határozták el, ${ }^{2}$ és az 1973-1976 közötti időszakra szóló első környezetvédelmi akcióprogram pedig lerakta a közösségi környezetpolitika alapjait. Ekkorra már az Európai Bíróság is észlelte a környezetvédelmi jog kiemelkedően fontos szerepét, és számos ítéletében megteremtette a környezetvédelmi jog (igaz, kifejezetten gazdasági szempontú) érvényesíthetőségét. Hasonló megoldás érvényesült az Egységes Európai Okmányt megelőzően a szerződési felhatalmazás tekintetében is: amennyiben jogalkotás vált szükségessé, úgy az EK Szerződés 100. cikke (a közös piac megvalósításához szükséges jogharmonizációra való felhatalmazást adó cikk) alapján került sor a szükséges jogszabályok megalkotására, arra hivatkozással, hogy a tagállamok eltérő környezetvédelmi elöírásai a termékek tekintetében közvetlenül befolyásolják a tagállamok közti kereskedelmet. ${ }^{3}$

Jelen tanulmány keretei között (figyelemmel a PhD kutatási témámra, amely a zajvédelem hazai és európai uniós szabályrendszerének tanulmányozása) megkísérelem felvázolni a környezetvédelmi jog legfontosabb alapelveit és alapintézményeit az uniós jogban, majd megkísérlem bemutatni mindezek gyakorlati alkalmazását - az uniós zajvédelmi szabályrendszer egyfajta áttekintése alapján. Terjedelmi okokból nem vállalkoztam az uniós zajvédelmi szabályok teljes körü (valamennyi zajforrásra vonatkozó) részletes elemzésére, az általam kiválasztott példa azonban meglátásom szerint jól mutatja azokat a szabályozási típusokat, ami az uniós környezetvédelmi jogon belül a zajvédelmi szabályozást jellemzi.

\section{A környezetvédelmi jog alapelvei az Európai Unió jogában}

Az Európai Közösség Tanácsa 1973-ban fogadta el az Első Környezeti Akcióprogramot, melynek máig ható jelentősége a környezetvédelmi jog összesen tizenegy alapelvének megfogalmazása, és mely elvek azóta is visszaköszönnek a későbbiekben elfogadott akcióprogramokban. Az elvek jogi jelentőségével kapcsolatosan Gerd Winter az alábbiakat tartja fontosnak kiemelni:

1. Az elveket úgy kell értelmezni, mint amelyeknek jogi kötelező erejük van, a nem jogi elveket politikáknak, céloknak, ideáknak, stb. kell nevezni.

2. A jogi értéket a jogalkotásból és a bírósági eljárásból lehet levezetni, ami elsősorban politikai döntés kérdése, másodsorban pedig a közös tapasztalat és a közös józan ész eredménye. 
3. Az elveket meg kell különböztetni a szabályoktól. Az elveket össze lehet vetni ellentétes elvekkel, míg a jogszabályok döntőek akkor is, ha kivételeket tartalmaznak, vagy kiegyensúlyozni próbálják az ellentétes szempontokat.

4. A szabályok az elvek közötti súlyozás során elsőbbséget adhatnak egy elvnek a többihez képest vagy éppen döntő mértékben prioritást biztosíthatnak.

5. Az elvek segítséget adnak a szabályok értelmezéséhez, kitölthetik a szabályozás hiányosságait, és új szabályokat alakíthatnak ki. ${ }^{4}$

A megelőzés elve az első akcióprogram elfogadása óta alapvető része az Európai Unió környezetpolitikájának, mely elv a harmadik környezeti akcióprogram központi kérdése is volt. Az elv gyakorlati alkalmazására példaként hozható a Deponiezweckverband Eiterköpfe kontra Land Rheinland-Pfalz ügyben 2005-ben lefolytatott elözetes döntéshozatali eljárás, ahol a 30. pont meglátásom szerint egyértelmüen az elv gyakorlati alkalmazására utal: a 75/442/EGK irányelv „olyan intézkedéseket ír elö, amelyek célja, hogy amennyire lehetséges, megakadályozzák vagy csökkentsék a hulladék lerakásából eredő környezetre gyakorolt negatív hatásokat.",

Egyes szerzők önálló elvként kezelik a forrásnál való fellépés elvét, mely annyiban hasonlít a megelőzés elvéhez, hogy mindkettő a veszélyhelyzet, illetőleg károk elkerülését célozza meg. A forrásnál való fellépés elve annyival haladja meg a megelőzés elvét, hogy ez már az eszközt is megjelölni igyekszik - így például magában foglalja a kibocsátási határértékek alkalmazásának elsőbbségét a kibocsátás megtörténtét követően értelmezhető környezetminőségi értékek alkalmazása helyett. ${ }^{6} \mathrm{Az}$ elv tartalmát az Európai Bíróság a Vallon hulladék ügyben a következők szerint fogalmazta meg: „Minden egyes régiónak, önkormányzatnak és más helyi hatóságnak a kötelessége, hogy tegyék meg a szükséges lépéseket annak érdekében, hogy saját hulladékukat gyüjtsék, kezeljék és ártalmatlanítsák, és ugyancsak annak érdekében is, hogy a keletkezés helyéhez képest a lehető legközelebb ártalmatlanítsák, hogy ennek révén lehetőség szerint korlátozzák a hulladékok szállítását."7

Az elővigyázatosság elve, mint az egyik legfontosabb környezetvédelmi jogi alapelv nem elsősorban az Európai Bíróság környezetvédelmi jogi tárgyú ítéleteiben érhető tetten. Az elsősorban versenyjogi szempontból elhíresült Sandoz-ügyben az Európai Bíróság rögzítette, hogy „a tudományos értékelésben rejlő bizonytalanság ismeretében igazolhatók azok a nemzeti intézkedések, amelyek előzetes engedély hiányában megtiltják az olyan élelmiszerek forgalmazását, amelyek hozzáadott vitaminokat tartalmaznak..." $\mathrm{Az}$ elővigyázatosság elve annyiban lép túl a megelözés elvén, hogy a következmények bizonyíthatóságának szintjén leszállítja a tudományos bizonytalanság szintjére. Ugyanezt még emblematikusabban az Európai Bíróság a kergemarhakór-ügyben fogalmazta meg talán a legtalálóbban. Az ügy alapjául szolgáló tényállás szerint a Bizottság 1996-ban határozattal megtiltotta a brit marhaés borjúhús behozatalát az Unió tagállamaiba a kergemarha-kórra hivatkozással, amit NagyBritannia túlzottnak talált, és az Európai Bíróságnál keresett jogorvoslatot. Az ítélet 99. pontja értelmében azonban „Amennyiben az emberi egészséget érintő kockázat létének vagy kiterjedésének megítélése bizonytalan, az intézményeknek lehetöségük van arra, hogy védelmi intézkedéseket fogadjanak el mindaddig, amíg a kockázat valóságtartalma és súlyossága teljesen világossá nem válik."9 Meglátásom szerint éppen ezért az elővigyázatosság elvének gyakorlati alkalmazása elsősorban valamilyen kockázatelemzésen alapulhat minden esetben.

A szennyező fizet elve már a kezdetektől fogva alapvető elve a közösségi környezetpolitikának, majd környezetjognak, melyet már az első akcióprogram is tartalmazott. A szennyező fizet elvét először egy 1975-ös tanácsi ajánlás tartalmazta tudomásom szerint, az alábbi megfogalmazásban: „A szennyezés elleni fellépés költségeinek a szennyezőkre hárítása ösztönzőként hat a szennyezés csökkentése irányában, illetve abban, hogy kevésbé szennyező termékeket és technológiákat alkalmazzanak, ami lehetővé teszi a 
környezeti erőforrások ésszerübb hasznosítását."10 A bírói gyakorlatban a szennyező fizet elvének közvetlen alkalmazására meglehetősen kevés példát találni. ${ }^{11}$

A védelem magas szintjének elvének sajátosságát az jelenti, hogy az elsődleges uniós jogban is megfogalmazásra került. A Lisszaboni Szerződéssel kötelező erejüvé vált Alapjogi Charta 37. cikke értelmében például „A magas színvonalú környezetvédelmet és a környezet minőségének javítását be kell építeni az uniós politikákba, és a fenntartható fejlődés elvével összhangban biztosítani kell a megvalósulásukat." Az elvvel kapcsolatos legnagyobb problémát meglátásom szerint az jelenti, hogy mást és mást jelent a védelem „magas szintje” a skandináv államokban, vagy éppen a déli és különösen az újonnan csatlakozott államok számára. Az Európai Bíróság is mindössze annyit tudott ezzel kapcsolatosan megállapítani, hogy ,amíg az vitathatatlan, hogy a Szerződés 130r cikkének (2) bekezdése megköveteli, hogy a Közösség környezeti politikája a magas szintü védelemre irányuljon, ez a védelmi szint, a kérdéses rendelkezéssel való összeegyeztethetőség érdekében nem jelenti a technikailag elérhető legmagasabb szintet." 12

A legkisebb szigor klauzulája, illetve a részben hasonló lehetőséget teremtő (az eltérés lehetőségét biztosító) védelmi záradék az uniós jogon belül sem elsősorban a környezetjognak köszönheti létrejöttét: az irányelvek és rendeletek jelentős része tartalmazott olyan záradékot, amelyek lehetővé tették a tagállamok számára, hogy egészségügyi vagy éppen környezeti okokból eltérjenek a közösségi követelményektől. ${ }^{13}$ Az Egységes Európai Okmány emelte ugyanakkor az elsődleges jogforrások szintjére a legkisebb szigor klauzuláját, amikor kimondta annak lehetőségét, hogy „bármely tagállam a jelen Szerződéssel összeegyeztethető szigorúbb védelmi szabályokat tartson fenn, vagy vezessen be". A védelmi záradék intézményét pedig az Amszterdami Szerződés emelte be végleges formájában az elsődleges jogba, a módosított 100a. cikk (4) bekezdésével, mely kimondta, hogy „Ha azt követően, hogy a Tanács vagy a Bizottság harmonizációs intézkedést fogadott el, egy tagállam a 30. cikkben említett lényeges követelmények alapján vagy a környezet, illetve a munkakörnyezet védelmével kapcsolatosan szükségesnek tartja a nemzeti rendelkezések fenntartását, ezekröl a rendelkezésekről és fenntartásuk indokairól értesíti a Bizottságot." Egy gyakorlati példa a legkisebb szigor klauzulája alapján történő eltérésre az Európai Bíróság esetjogából a már említett Deponiezweckverband Eiterköpfe kontra Land Rheinland-Pfalz ügyben zajlott előzetes döntéshozatali eljárás ahol a Bíróság rögzítette, hogy „Következésképpen az első kérdésre azt a választ kell adni, hogy az irányelv 5. cikkének (1) és (2) bekezdésével nem ellentétes egy olyan nemzeti intézkedés, amely

- az irányelvnél szükebb korlátokat állapít meg a biológiailag lebontható hulladékoknak a hulladéklerakóban való átvételére, még ha e korlátok olyan szükek is, hogy szükségessé teszik a hulladéklerakóban való elhelyezést megelőzően a hulladékok biológiai-mechanikus kezelését vagy égetését,

- az irányelvnél rövidebb határidőket állapít meg a hulladéklerakóban elhelyezett hulladék mennyiségének csökkentésére,

- nemcsak a biológiailag lebontható hulladékokra vonatkozik, hanem a biológiailag le nem bontható szerves anyagokra is, és

- nemcsak a települési hulladékra, hanem a települési hulladékkal azonos módon ártalmatlanítható hulladékra is vonatkozik."14

Fontos hangsúlyozni, hogy a környezetjog számos területe igényli az uniós szintü szabályozást, azonban ezen szabályok (különösen, ahol a tagállamok lehetőséget kapnak a védelmi záradék vagy a legkisebb szigor klauzulája alkalmazására) könnyen válhatnak a diszkrimináció eszközévé, ezért alkalmazásuk fokozott indokoltságot és ellenörzést igényel. Éppen ezért ezeket a rendelkezéseket az Unió egész jogrendszerével összefüggésben célszerü vizsgálni, ideértve az arányosság, jogbiztonság, vagy éppen a szubszidiaritás elvét is - mely elvek részletes bemutatását (lévén nem speciálisan környezetjogi elvek) ezúttal mellőzöm. 


\section{Igazgatási eszközök és eljárások az uniós környezetvédelmi jogban}

A magyar környezetvédelmi eljárásjog müködéséhez hasonlóan, az uniós jogalkotás és jogalkalmazás is a környezet védelmét szolgáló közigazgatási eszközök széles skáláját ismeri és alkalmazza a másodlagos jog keretei között.

A bejelentés (notifikáció) akkor alkalmazandó, amikor nincs közvetlen engedélyezési kötelezettség ugyan, ám a hatóságoknak tudomással kell bírniuk a kérdéses környezethasználat, környezetterhelés mikéntjéröl. A bejelentési kötelezettséggel bíró jogforrások közül talán a legismertebb az ipari baleseti kockázatra vonatkozó ún. Seveso II. irányelv, ${ }^{15}$ melynek értelmében az üzemeltető a hatóságnak köteles írásban bejelenteni a telephely müködését. A bejelentés intézményére azért van szükség, mert „az illetékes hatóságoknak az előzetes bejelentés által pontos tájékoztatást kell kapniuk... hogy megtehessenek minden szükséges intézkedést az emberi egészség és a környezet védelmében."16 A bejelentés alapján az illetékes hatóságok természetesen jogosultak az általuk szükségesnek tartott valamennyi intézkedés megtételére. ${ }^{17} \mathrm{~A}$ bejelentés egy sajátos esete, amikor valamely, irányelvben lefektetett követelmény teljesítését a tagállam köteles a Bizottságnak bejelenteni. ${ }^{18}$

A bejelentéshez hasonló tartalmú szabályt jelent a nyilvántartásba vétel (regisztrálás) követelménye, amely általában a bejelentéshez kapcsolódik. A bejelentések és nyilvántartások eszközeinek alkalmazása leginkább a veszélyes anyagok és készítmények szabályozási körében jellemző, ${ }^{19}$ de más területeken (így például az európai természeti területek hálózatáról szóló Natura 2000 területen is) találhatunk rá példát. Érdekességképpen megemlítem, hogy a hulladékgazdálkodás kapcsán egyenesen két értelemben is beszélhetünk nyilvántartásról: egyfelől, nyilván kell tartani azon vállalkozásokat, amelyek hivatásszerüen végeznek hulladékgyüjtést vagy szállítást, másfelöl ugyancsak lényeges, hogy ezen vállalkozások nyilvántartsák a hulladékok mennyiségét, tulajdonságait és kezelési módszereit. A bejelentés vagy nyilvántartásba vétel következménye lehet, illetve ezen eljárások viszonyítási alapjául is szolgálhat az egyes anyagok, termékek, tevékenységek osztályozása, mely tipikusan környezeti veszélyesség vagy környezeti állapot alapján történik, így az egyes besorolási osztályokhoz eltérő jogszabályi követelmények is társulnak. Az osztályozás azonban nem csupán a környezetjog sajátossága: az Európai Unió versenyjogában is találkozhatunk például „listákkal” aszerint, hogy bizonyos magatartásokat engedélyezettnek, vagy éppen tiltottnak kell-e tekinteni az Unió joga alapján. Az Európai Bíróság is felhívta azonban a figyelmet arra, hogy az osztályozás „,nem harmonizálja azokat a követelményeket, amelyek alapján a veszélyes anyagokat piacra lehet juttatni vagy használni lehet", ${ }^{20}$ azaz az osztályozás nem azonosítható a használat szabályozásával.

A környezetvédelmi jogban a megelőzés elvének érvényre juttatásához a legjobb eszköznek az engedélyezés tekinthető. Az engedélyezés a bejelentéshez képest sokkal közvetlenebb beavatkozást jelent a környezethasználó tevékenységébe, hiszen meghatározza azokat az alapvető feltételeket, amelyek keretei között az adott tevékenység folytatható. Engedélynek általában a hatáskörrel rendelkező hatóság olyan döntését tekintjük, amely feljogosítja a kérelmezőt valamely tevékenység folytatására. ${ }^{21}$

A termékminősítés és annak különböző változatai egyre több területen jelennek meg, összefüggésben a termékek életciklusának elemzésével, illetve a gazdaság és környezet érdekei közötti integráció biztosításának szükségességével. A termékminősítés annyiban hasonlít az engedélyhez, hogy az is a termék forgalomba helyezésének és forgalomban tartásának a feltétele. A termékminősítés legjobb példája éppen a szűkebb kutatási témámnak tekinthető zajvédelem területéről hozható, az ún. típusjóváhagyás, melynek legelső példája a Tanács 70/157/EGK irányelve a gépjármüvek megengedett zajszintjére és 
kipufogórendszereire vonatkozó tagállami jogszabályok közelítéséről szól. Ennek egyik alapvető esete a zajtanúsítványok, vagy egyedi megfelelőségi tanúsítványok kibocsátása. A termékjelzés fö célja, hogy egységes követelményrendszert vezessen be az egyes termékekre, illetőleg azok forgalmát mozdítsa elö, amely termékek a követelményeket teljesítik - oly módon, hogy megfelelő tájékoztatással látja el a potenciális vásárlókat.

Azon esetekben, amikor közvetlen és gyors beavatkozás szükséges, a hatóságok élhetnek a tiltás és kötelezés eszközével. A közvetlen és gyors közigazgatási beavatkozás jellegéből adódóan ezt az intézményt az Európai Unió csak egészen kivételes, kiemelt esetekben nevesíti - így például az osztályba sorolt vízminőségi követelmények következményeként az ún. A3as vízminőségi kategóriánál rosszabb felszíni vizek használatát a jogalkotó megtiltotta. A tilalmi rendszerek gyakran az engedélyek helyett, mintegy azok alternatívájaként használhatóak - amennyiben ezek hatékonyságát megfelelően igazolni lehet. ${ }^{22}$ Miután a tilalmak és kötelezések nem hagynak semmilyen mérlegelési lehetőséget a tagállamok számára, ezért nem meglepő módon azon esetekben, ahol az Európai Unió célja a szerteágazó tagállami gyakorlatok egységesítése, egyre fokozódó mértékben él ezzel az Unió.

A jogalkalmazás és jogérvényesítés számára minden esetben nélkülözhetetlen az ellenőrzési eszközök minél teljesebb körének felhasználása, ami különösen igaz a környezetvédelmi jog rendszerére. ${ }^{23} \mathrm{Az}$ ellenőrzésnek természetesen elő kell segítenie a vonatkozó jogszabály hatékony végrehajtását. Az Európai Bíróság egy (a madarak felhasználásával kapcsolatos ügyhöz kötődő előzetes döntéshozatali eljárásban) úgy foglalt állást, hogy az ellenőrzésnek „nemcsak azt kell biztosítania, hogy az irányelvben szabályozott védelmi rendszertől való eltéréseket engedélyező határozatok jogszerüsége ésszerü időn belül megvizsgálható legyen, hanem azt is, hogy betartsák az említett határozatokhoz rendelt feltételeket."24

A hatodik környezetvédelmi akcióprogram külön prioritásként kezelte az önkéntes eszközök alkalmazását, melynek alapja a Bizottság 1996. november 27-i kommünikéje volt. ${ }^{25} \mathrm{Az}$ önkéntes eszközökre példaként hozható a csomagolási hulladékok szabályozása, ahol az érintett felek együttmüködésén alapuló hulladék-összegyüjtési és -hasznosítási rendszerek kialakítására került sor a tagállamok közremüködésével. ${ }^{26} \mathrm{Az}$ önkéntes megállapodások a nemzeti vagy uniós jogalkotás helyett kerülnek alkalmazásra, és hatékonyságuk nagymértékben függ a résztvevő felek hajlandóságától. Ugyanakkor, éppen a szabályozás önkéntessége biztosítja, hogy az elfogadott megoldás a lehető leginkább vegye figyelembe az abban részes felek érdekeit - ami pedig feltételezi az érintettek részéröl az adott szabályok betartását is. Ugyan a megállapodásra tipikusan az állami hatóságok és valamely ágazati szervezetek között kerül sor, nincs annak sem akadálya, hogy egyes hatóságok jussanak egymás között valamilyen, a jogszabályi keretek által biztosított megállapodásra - bár erre konkrét példát az uniós joggyakorlatból nem tudok említeni.

Az ún. gazdasági eszközök alkalmazására az uniós jog egyelöre még csak utalásokat tartalmaz, azzal, hogy minden konkrét elöírás már a tagállamok hatáskörébe tartozik. Megítélésem szerint (az ötödik környezetvédelmi akcióprogram alapján) ezen eszközök alkalmazása egyre jelentősebbé válik. A Bíróság megállapította például, hogy nincs akadálya adott esetben kifejezetten környezeti adók alkalmazásának sem, amennyiben azok ,a diszkrimináció minden formáját kizárják, legyen az akár közvetett, akár közvetlen a más tagállamokból származó termékekkel kapcsolatban, illetve kizárják a versengő hazai termékek védelmének bármely formáját." ${ }^{27}$ Érdekes megemlíteni, hogy ugyancsak gazdasági eszköznek minősülnek a tagállamok által egyes közigazgatási szolgáltatásokért igényelhető díjak is, melyek nem csak abban az esetben vethetőek ki, ha azt egy uniós jogszabály kifejezetten tartalmazza, hanem akkor, ha azokat nem tiltja meg kifejezetten az uniós joganyag. ${ }^{28}$

Az egyes kategóriák között adott esetben lehetséges az átjárás: az ökocímke, vagy más néven környezeti termékjelzés az uniós gyakorlatban például mind gazdasági eszközként, mind pedig az önszabályozás egyik lehetséges módjaként értelmezhető. 


\section{Zajvédelmi szabályok az uniós jogban}

A zajvédelem európai uniós kulcsdokumentumának az Európai Parlament és a Tanács 2002/49/EK irányelve tekinthető, mely „a környezeti zaj értékelésérő és kezeléséről” címet viseli. Az irányelv nem tekinthető előzmények nélkülinek az uniós jogban: a Bizottság már 1997-ben elfogadott egy zöld könyvet a jövő zajpolitikájáról, majd ezt követően egyes közösségi jogszabályok szektorális szinten igyekeztek szabályozni a zajkibocsátás egyes eseteit. Ekként, külön jogszabály vonatkozik a gépjármüvek zajszintjére, ${ }^{29}$ a traktorok vezetöi által érzékelt zajszintekre, ${ }^{30}$ a szubszonikus repülőgépek zajkibocsátásának korlátozására, ${ }^{31}$ vagy éppen a kültéri használatra tervezett berendezések környezeti zajkibocsátására. ${ }^{32}$

A zajvédelem uniós szintű szabályozása során (figyelemmel az uniós jogban létező szubszidiaritás elvére) lényeges kérdés annak vizsgálata, hogy a fellépés mely szintjét kell feltétlenül uniós szinten megvalósítani, és mely lépések kivitelezése kívánatos inkább tagállami szinten. A 2002/49/EK irányelv (miként a legtöbb környezetvédelmi tárgyú irányelv) akként rendelkezik, hogy a környezeti zajszintekre vonatkozó adatok összegyüjtése és rendszerezése összehasonlítható kritériumok és módszerek alapján valósítandó meg. ${ }^{33} \mathrm{Az}$ irányelv alapján ennek gyakorlati megvalósulása az alábbiak szerint kell, hogy megtörténjen:

- a tagállamok közös értékelési módszereinek alkalmazásával készített zajtérképek révén a környezeti zajnak való kitettség mértékének meghatározása;

- annak biztosítása, hogy a környezeti zajra és annak hatásaira vonatkozó információk a közvélemény rendelkezésére álljanak;

- cselekvési tervek tagállami szintü elfogadása a zajtérképek alapján, a környezeti zajnak a szükséges helyeken történő megelőzése és csökkentése érdekében. ${ }^{34}$

Az irányelv környezeti zaj alatt minden, emberi tevékenység révén keltett nem kívánatos vagy káros kültéri hangot jelent, ideértve a közlekedés, a közúti, vasúti és légi közlekedés eszközei által keltett zajt, valamint egyes ipari tevékenységek telephelyeiből származó zajt is. ${ }^{35}$ Fontosnak tartom megjegyezni, hogy a magyar Jövő Nemzedékek Országgyülési Biztosa gyakorlata alapján nem feltétlenül szerencsés egységesen „környezeti zajról” beszélnünk, hiszen az eltérő zajforrások és hatásterületek eltérő szabályozási módszerek megvalósítását indokolhatják. Eszerint különbséget kell tennünk:

- közlekedéssel kapcsolatos zajterhelés (értve ez alatt különösen a lakások közelében húzódó autópályák, autóutak miatt megnövekedő forgalom okozta zajterhelést, valamint a repülőterek müködésével összefüggő zajterhelést);

- közterületi rendezvények okozta zajterhelés (értve ez alatt a különféle szabadtéri rendezvények okozta zajhatásokat);

- szabadidős zajforrások (értve ez alatt különösen egyes szórakozóhelyek éjszakai nyitva tartásának kérdéseit, és ekként különösen a pihenéshez és szórakozáshoz való jogok összeütközését);

- és végezetül üzemi zajforrások (ipartelepek, gyárak rendeltetésszerü müködésével kapcsolatos zajterhelés) között.

A környezeti zaj értékeléséről és kezeléséről szóló irányelv tagállami jogba történő átültetése nem ment zavartalanul a tagállamokban, ezt példázza egyebek között a C-138/06. számú ügy, melyben az Európai Bizottság kérelmére az Európai Közösségek Bírósága megállapította, hogy az Egyesült Királyság elmulasztotta az irányelv határidőben történő implementálására vonatkozó kötelezettségét. ${ }^{36}$ A jogeset egyben arra is példaként hozható, hogy a környezetvédelmi jog tárgykörébe tartozó jogesetek nem csak közvetlenül (kifejezetten a tárgyuk miatt), hanem közvetetten, az uniós jogforrások tartalmától függetlenül folyó eljárásokban is felhívhatók. 
Felmerülhet a kérdés, hogy egy eredendően gazdasági jellegü nemzetközi szervezet miért tartja fontosnak a környezetvédelem egy speciális szegmensének a szabályozását. A választ az Európai Bizottság $\operatorname{COM}(2008)$ 432. számú, „A meglévő vasúti jármüállomány zajkibocsátásának csökkentését célzó intézkedések" címet viselő közleménye alapján kísérelem meg bemutatni, az alábbiak szerint.

A közlemény hangsúlyozza, hogy a fejlett ipari országokban a zaj a közegészséget veszélyeztető egyik legjelentősebb tényező, és egyes európai régiókban a vasúti zaj kapcsán a lakosság élénk tiltakozásának szokott hangot adni. Ami miatt a kérdés az Unió illetékes testületeinek napirendjére is került, az az a tény, hogy a vasút az egyik leginkább környezetbarát szállítási módnak tekintendő, ${ }^{37}$ mely ebbéli minőségében pedig már közvetlenül is összefüggésben van a négy alapvető szabadság biztosításának kötelezettségével. A probléma összetettségét jól mutatja, hogy a Bizottság megítélése szerint, amennyiben az Unió nem tesz intézkedéseket a vasúti kocsik (különösen a teherkocsik) zajszintjének csökkentése irányába, akkor a lakossági tiltakozások hatására csökkenni fog a legjelentősebb európai vasúti folyosók kapacitása, ami már önmagában is kedvezőtlen hatást fog gyakorolni az európai országok gazdaságára. ${ }^{38}$ Ráadásul, ha ezeken a szállítási folyosókon a szállítási arány eltolódna a vasúti közlekedéstől a közúti közlekedés irányába, az jelentősen megnövelné az Unió tagállamai tekintetében az üvegházhatású gázok kibocsátásának mértékét - ami pedig már a kiotói jegyzőkönyvbe foglalt célok teljesítését is veszélyeztethetné.

A környezetvédelmi jogi szabályozó eszközöket aszerint csoportosíthatjuk, hogy a szabályozási célt közvetlen, vagy közvetett módon kívánják-e elérni. Amíg a közvetlen szabályozási eszközök kifejezetten valamely magatartás követését támogatják, vagy éppen tiltják, addig a közvetett szabályozási eszközök anyagi érdekeltség révén kívánják a jogalanyok helyes magatartását elömozdítani. A Bizottság említett közleménye mindkét megoldásra mutat példát.

Közvetett szabályozási eszközként javasolja a Bizottság bevezetni a differenciált pályahasználati díj intézményét. Lényeges hangsúlyozni, hogy a díjszabási elveket európai szinten már jelenleg is rögzíti egy irányelv, ${ }^{39}$ mely elvek egyike kimondja, hogy az infrastruktúra-használati díjak meghatározásakor figyelembe lehet venni az egyes vasúti müveletek által okozott környezeti hatások (így például a zajkibocsátás) költségét. ${ }^{40}$ Meglátásom szerint a differenciált pályahasználati díj háromféle modellen alapulhat:

- bonus-malus rendszer, mely az alacsonyabb zajkibocsátású teherkocsikra alacsonyabb, a zajosabb teherkocsikra pedig magasabb díjakat állapít meg;

- olyan bonus-rendszer, mely a már meglevő vasúti kocsik zajkibocsátását utólagos modernizáció révén csökkentő beruházásokért cserébe pályahasználati dijkedvezményt biztosít;

- olyan malus-rendszer, mely a zajosabb teherkocsikra megnövelt díjakat szab ki (anélkül azonban, hogy a beruházásokért cserébe bármilyen kedvezményt biztosítana).

A Bizottság közleménye maga is utal arra, hogy az ilyen közvetett szabályozási eszközök felvethetik az állami támogatásokra vonatkozó uniós szabályokkal való összeegyeztethetőség kérdését, azaz a nyújtandó támogatásoknak

- lehetőség szerint csak egy korlátozott időszakra kellene vonatkozniuk;

- egyenlő és megkülönböztetéstől mentes feltételek mellett valamennyi rendszerhasználó számára biztosítani kell a hozzáférés lehetőségét;

- a támogatás mértékének arányban kell állnia az elérendő célokkal. ${ }^{41}$

Közvetlen szabályozási eszköznek tekinthető a zajkibocsátási határértékek bevezetése, mely egy adott vasútvonal mentén található mérési pontra vonatkozóan állapít meg egy adott időszakra jellemző átlagos kibocsátási határértéket. A 2002/49/EK irányelv értelmében a tagállamok jogosultak arra, hogy a környezeti zaj tekintetében ilyen határértéket rögzítsenek. 


\section{Összegzés}

Magyarország Európai Uniós csatlakozása az élet számos területén rendkívül komoly változtatásokat hozott. Nem volt ez másképp a környezetvédelmi jog területén sem, mint ahol talán a legnagyobb szemléletváltozásra volt-van szükség a magyar jogalkotási és föleg jogalkalmazási gyakorlatban. Jelen tanulmány keretei között elsősorban terjedelmi okokból nem vállalkoztam arra, hogy összevessem az uniós környezetvédelmi jogi szabályok gyakorlati megvalósulását a magyar helyzettel. Megítélésem szerint az elmúlt években egyértelmüen megfigyelhető volt a magyar környezetvédelmi jogi gondolkodásmód lassú, de folyamatos változása - az Európai Unióban kívánatosnak tartott szint irányába. Sajnálatos módon azonban (miként azt egy korábbi, a termékdíjjal kapcsolatos, Horváth M. Tamás Professzor Úrnak írt tanulmányomban is kifejtettem) a magyar jogalkotó számára a környezetvédelmi jogi szabályok betartása még ma is csak egyfajta tehertételként értelmezhető, azonban bízom benne, hogy például a magyar EU-elnökség hangsúlyos környezetvédelmi jogi prioritásai is hozzájárulnak majd e gondolkodásmód változásához. ${ }^{42}$

\footnotetext{
${ }^{1}$ Ügyvédjelölt; PhD hallgató, MG ÁJDI

${ }^{2}$ Várnay Ernő - Papp Mónika: Az Európai Unió joga (KJK-Kerszöv, Budapest, 2003.) 594. o.

${ }^{3}$ Várnay Ernő - Papp Mónika: Az Európai Unió joga (KJK-Kerszöv, Budapest, 2003.) 595. o.

${ }^{4}$ Gerd Winter: The Legal Nature of Environmental Principles. In: Richard Macrory (szerk.): International, EC and German Law in Principles of European Environmental Law. Groningen, 2004, 27-28. o.

${ }^{5}$ C-6/03. számú ügy, 30. pont (ECR 2005 I-02753).

${ }^{6}$ Jan H. Jans - Hans H. B. Vedder: European Environmental Law. Groningen, 2008, 42. o.

${ }^{7}$ C-2/90. számú, Bizottság kontra Belgium ügy, 1992. (ECR 1992 I-04431) 34. pont

${ }^{8}$ C-174/82. számú, előzetes döntéshozatali eljárás a Societe Sandoz BV ellen indult büntetőeljárásban (ECR 1983 02445) 17. pont

${ }^{9}$ C-180/96. számú, Egyesült Királyság kontra Bizottság ügy, 1998. (ECR 1998 I-02265) 99. pont

10 75/436/Euratom, ESZAK, EGK Tanácsi ajánlás

${ }^{11}$ C-293/97. számú ügy, előzetes döntéshozatali eljárás Standley és Metson és Társaik, valamint a Korona és az Egyesült Királyság mezőgazdasági és környezetvédelmi minisztere elleni ügyben, 1999 (ECR 1999 I-02603) 51. pont: „Ami a szennyező fizet elvét illeti, elegendő azt leszögezni, hogy az irányelv nem jelenti azt, hogy a farmereknek kellene vállalniuk azon szennyezés felszámolásának terheit, amelyhez nem is járultak hozzá."

${ }^{12}$ C-284/95. számú, előzetes döntéshozatali eljárás a Safety Hi-Tech Srl és a S. \& T. Srl. közötti ügyben, 1998. (ECR 1998 I-04301) 49. pont

${ }^{13}$ Ludwig Kraemer: EC Environmental Law, London, 2003, 133. o.

${ }^{14}$ C-6/03. számú ügy, 56. pont (ECR 2005 I-02753).

15 A Tanács 96/82/EK irányelve (1996. december 9.) a veszélyes anyagokkal kapcsolatos súlyos balesetek veszélyeinek ellenőrzéséről

${ }^{16}$ C-215/04. számú ügy, előzetes döntéshozatali eljárás, amelyet a l’Ostre Landsret (Denmark) utalt a Bíróság elé a Marius Pedersen A/S vs. Miljostyrelsen ügyben, 2006 (ECR 2006 I-01465) 46. pont

${ }^{17}$ lásd például: C-472/02. számú ügy, előzetes döntéshozatali eljárás, amelyet a Cour d'appel de Bruxelles (Belgium) terjesztett elő a Siomab SA és az Institut Bruxellois pour la Gestion de 1'Environement között folyamatban levő eljárásban, 2004 (ECR 2004 I-09971) 27-28. pontok

18 lásd például: C-266/99. számú ügy, Bizottság kontra Franciaország, 2001 (ECR 2001 I-0981) 42. pont, melyben a Bizottság egyebek között azért kezdeményezett eljárást Franciaországgal szemben, mert az nem tájékoztatta a Bizottságot a 75/440/EGK irányelv 4. cikk (3) bekezdésének megfelelően arról, hogy Britanny vizeiben gyenge minőségü felszíni vizeket használ az ivóvíz kinyerésére.

${ }^{19}$ lásd például a Tanács 67/548/EGK számú, 1967. június 27-i irányelvét a veszélyes anyagok osztályozására, csomagolására és címkézésére vonatkozó törvényi, rendeleti és közigazgatási rendelkezések közelítéséről

${ }^{20}$ C-473/98 számú ügy, előzetes döntéshozatali eljárás, amelyet a Kammarratten i Stockholm (Sweden) utalt a Bíróság elé a Kemikalieinspektionen és a Toolex Alpha AB közötti ügyben, 2000 (ECR 2000 I-05681)

${ }^{21}$ lásd például a Tanács 85/337/EGK irányelvét (1985. június 27.) az egyes köz- és magánprojektek környezetre gyakorolt hatásainak vizsgálatáról, különösen az irányelv 1. cikk (2) bekezdését

${ }_{22}$ C-282/02. számú ügy, Bizottság kontra Írország, 2005. (ECR 2005 I-04653) 78. pont

${ }^{23}$ lásd például a C-221/03. számú ügyet, Bizottság kontra Belgium, 2005 (ECR 2005 I-08307), különösen a 138. pontot
} 
${ }^{24}$ C-60/05. számú ügy, előzetes döntéshozatali eljárás, WWF Italia és társai kontra Regione Lombardia ügy, 2006 (ECR 2006 I-05083) 44. pont

${ }^{25}$ Commission Communication on Environmental Agreements, COM(96) 561, 1996. november 27.

${ }^{26}$ Az Európai Parlament és a Tanács 94/62/EK irányelve (1994. december 20.) a csomagolásról és a csomagolási hulladékról

${ }^{27}$ C-213/96. számú ügy, előzetes döntéshozatal iránti kérelem, Uudenmaan laaninoikeus elöterjesztése az Outukumpu Oy ügyben (Finnország), 1998, (ECR 1998 I-01777) 30. pont

${ }^{28}$ C-216/05. számú ügy, Bizottság kontra Írország, 2006 (ECR 2006 I-10787) 28. pont

${ }^{29} 70 / 157 /$ EGK irányelv

30 77/311/EGK irányelv

${ }^{31} 80 / 51 /$ EGK irányelv

32 2000/14/EK irányelv

${ }^{33}$ 2002/49/EK irányelv (7) bekezdés

${ }^{34}$ 2002/49/EK irányelv 1. § (1) bekezdés

35 2002/49/EK irányelv 3. § a, pont

${ }^{36}$ C-138/06. számú, Bizottság kontra Egyesült Királyság ügy

${ }^{37}$ Közlemény 2. o.

${ }^{38}$ Közlemény 2. o.

${ }^{39}$ 2001/14/EK irányelv

${ }^{40}$ lásd az irányelv 7. cikk (5) bekezdését, mely szerint „Az infrastruktúra-használati díj módosítható úgy, hogy figyelembe vegye az adott vonat közlekedtetése által okozott környezeti hatások költségét. A módosítást az okozott hatás nagyságának megfelelően kell differenciálni."

${ }^{41}$ Közlemény 7 . oldal

42 http://www.eu2011.hu/hu/dokumentum/sajtokozlemeny-magyar-soros-elnokseg-bemutatja-klimapolitikaiprioritasait (2011. január 23-i letöltés) 